\title{
Integrációs mechanizmusok
}

Kovách Imre (szerk.) (2020): Integrációs mechanizmusok a magyar társadalomban. Budapest: MTA Társadalomtudományi Kutatóközpont - Argumentum

\section{FÓNAI MIHÁLY1}

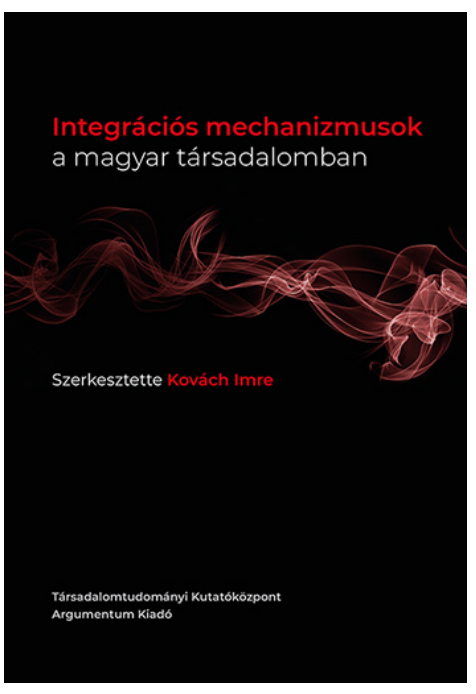

Az integrációs mechanizmusokat elemző kutatócsoportnak $^{2}$ (és a hozzájuk szorosan kapcsolódó kutatóknak) nem ez az első, nagylélegzetű munkája. A kutatócsoport tagjai az ezredforduló óta vizsgálják a magyar társadalom egyenlőtlenségi, hatalmi viszonyait, és az ezekkel a kérdésekkel szorosan összefüggő integrációs folyamatokat. A tágabban vett kutatócsoport (és az MTA TK „szűkebb" kutatócsoportja) e kérdések elméleti konceptualizálását is elvégezte az elmúlt két évtizedben, ezek az elméleti kérdésfelvetések jelentek meg a „Társadalmi metszetek” és a „Társadalmi integráció” című válogatott kötetekben. Törekvésük egyrészt a társadalmi rétegződés és a társadalmi integráció elméleti aspektusainak és fogalmainak az átgondolása, a lehetséges új megközelítések kidolgozása volt. Jelen kötet (és a mobilitási is $)^{3}$ ennek a közös gondolkodásnak az eredményeire épít, azt a fogalmi apparátust alkalmazzák, melyeket a korábbi kutatások és elemzések során kialakítottak. Az elméletek újragondolása és a fogalmak konceptualizálása együtt járt a kialakított elméleti modellek empirikus tesztelésének a megvalósításával, ehhez a kutatók a fogalmi apparátus kialakításával csaknem egyidejűleg operacionalizálták a fogal-

${ }^{1}$ Debreceni Egyetem, Állam- és Jogtudományi Kar; Humán Tudományok Doktori Iskola, e-mail: fonai.mihaly@law.unideb.hu

${ }^{2}$ A kutatások és a kötet az MTA Kiválósági Együttműködési Program (KEP), Mobilitás Kutatási Centrum keretében készültek. A projekt fogta össze a 2018 őszén 2700 fős mintán folytatott kutatást, melyen a kötetek elemzéseinek egy része alapul.

${ }^{3}$ Kovách Imre (szerk.) (2020): Mobilitás és integráció a magyar társadalomban. MTA Társadalomtudományi Kutatóközpont - Argumentum. 


\section{RECENZIÓ}

makat, dolgozták ki azok mérhetőségének eljárásait, a lehetséges változókat. Emiatt az elméleti keretek megfogalmazása és azok empirikus mérése, tesztelése között nagyon rövid idő telt el, erről tanúskodik a két, korábban kiadott kötet, és a most bemutatandó könyv is.

A „kiterjesztett” kutatócsoport tagjai saját kutatási területük elméleti és empirikus elemzésével, illetve kutatásával járultak hozzá a bemutatott kutatási eredmények létrehozásához. Ez a kutatócsoporton belüli, átgondolt munkamegosztásra utal, a kutatók teljesítménye szinergikus, egymás eredményeire alapoznak és azokat kölcsönösen figyelembe veszik (ez a megelőző kötetekben és a jelen kötetben megfigyelhető kereszthivatkozásokban is megfogható). A kötet sok szempontból a projekt lezárását, összefoglalását jelentő, szintetizáló mű (hasonlóan a „mobilitás” kötethez). Ez természetesen azzal is együtt jár, hogy az egyes kutatók saját területükön évek óta publikálnak a társadalmi integráció és a társadalmi mobilitás kérdéseiről, és ezekre az eredményekre erősen támaszkodnak a kötetbeli írásaikban. Ez természetes folyamata a kutatásoknak és az alkotómunkának, a tanulmányok szerzői olykor azonban feltételezik, hogy az olvasó ismeri ezeket az írásokat, ezért csak utalnak az azokban kifejtettekre - bár, tegyük hozzá, az elméleti kérdések kifejtésénél a részletesebb elemzésre és ismertetésre törekednek. A kötet „üzenete” a szerkesztési elveknek és az összehangolt munkának köszönhetően megfelelően világos és egyértelmű. A kötet felépítése az általánosabb kérdésektől halad a sajátos kérdéseket, problémákat megfogalmazók felé, ez utóbbi írások egy része a „tágabb” kutatói kör tevékenységéhez kapcsolódik.

Egy fontos megjegyzés a recenzens megközelítésmódjáról: a kötet kapcsán recenzió, és nem könyvkritika készült, emiatt a lehetséges teoretikus kapcsolódásokról, a meglévő hiányosságokról, egyensúlytalanságokról kevésbé írok, alapvetően a kötetek bemutatására vállalkozom - ezt az is indokolhatja, hogy a kötet a maga területén a magyar szociológia fontos és aktuális eredményeit foglalja össze a magyar társadalomról, sok szempontból az új szintézis igényével. A továbbiakban a kötet írásait mutatom be. A tanulmányok elolvasása után azért maradt hiányosságérzetem. Ez az oktatás és a felsőoktatás elemzésére vonatkozna, hisz mindkettőnek komoly szerepe van a társadalom integrálásában és a mobilitásban is. Talán erősebben kellett volna utalni a romák helyzetére, az ő össztársadalmi integráltságuk és mobilitásuk problémáira is.

Kiknek ajánlom a kötetet? A „szociális” szakmák és kutatók mellett az érdeklődo laikusoknak, és mindazoknak, akik egy participatív megközelítésben a mindannyiunkat érintő döntések részesei lehetnek. 


\section{RECENZIÓ}

Az „integrációs” kötet ${ }^{4}$ a következő blokkokból épül fel: Társadalmi egyenlőtlenségek és társadalmi integráció; Kormányzás és integráció; Integrációs rendszerek; A részek és az egész.

Az integrációs mechanizmusokat vizsgáló kötet első írása a Társadalmi integráció és társadalmi rétegződés című (Kovách Imre, Szabó Andrea, Huszár Ákos, Kristóf Luca).

A tanulmány szerzői kérdésként fogalmazzák meg, hogy hogyan függ össze az egyének társadalmi integrációja a társadalmi egyenlőtlenségek rendszerében elfoglalt helyükkel, és milyen integrációs mechanizmusok segítik elő, vagy éppen kényszerítik ki a társadalmi pozíció és az integráltság kölcsönhatásait. Utalnak arra, hogy a rétegződéskutatás klasszikus elméleteiben a társadalmi javak elosztása összekapcsolódik a társadalmi integráció kérdéseivel. Velük szemben a társadalom normatív integrációját hangsúlyozó funkcionalisták azokat a strukturális, rétegződési okokat is igyekeznek feltárni, melyek veszélyeztetik a társadalom normális integrációját. A szerzők (és az egész kutatás) a mertoni inspiráció adaptálására törekszik (a társadalmi normákhoz való alkalmazkodást illetően). Ehhez a részvételt, a gyenge kötések számát és a kirekesztés érzetét veszik figyelembe.

A társadalmi integrációs folyamatok vizsgálata a kutatássorozat és a kötet központi kérdését jelenti. Ehhez a társadalmi integrációs folyamatok három szintjét különböztették meg: a rendszerintegrációt, a társadalmi integrációt és a személyközi integrációt. A személyközi integráció fókusza az, hogy miként érzik magukat a szúken vett életvilágukban az emberek. A társadalmi integráció módozatokat, cselekvéseket, eszközöket jelent, melyeken keresztül a társadalom tagjai egymásra hatnak, és elfogadják összetartozásukat. A rendszerintegráció azokat a politikai és társadalmi cselekvéseket, aktivitásokat, beállítódásokat és normákat foglalja magába, melyek növelik a társadalmi és a politikai kohéziót, és csökkentik a konfliktusok kialakulásának az esélyét. Ezeknek az ideáltípusoknak a „varázstalanítása” (operacionalizálása) két lépésben történt a kutatás során: elsőként azokat a dimenziókat ragadták meg a kutatók, melyek az integrációs szintek főbb területeit jelentik, majd ezekben a dimenziókban történt meg az empirikus mérhetőség kialakítása. A rendszerintegráció szintjét így a politikai alrendszerrel összefüggő mechanizmusok, intézmények, tudások, normák és értékek fedik le. A társadalmi integráció kapcsán a redisztribúciós és térbeli folyamatokat és a társadalmi tőkeváltozókat emelték ki. A személyközi integrációhoz a társadalmi kapcsolatok és bizonyos aspektusokból a normák és az értékek tartoznak. A kutatási eredmények közül csak néhányat emelek ki. A gazdaságilag aktív státusszal, magasabb foglalkozási pozícióval több gyen-

\footnotetext{
${ }^{4}$ Az integrációs kutatáshoz 2015-ben kialakított integrációs csoportok a következők: kapcsolatgazdag politikailag aktívak, lokálisan integráltak, normakövető munkaerőpiacon integráltak, normakövető kapcsolatgazdagok, normaszegő munkaerőpiacon integráltak, normakövető dezintegráltak, kirekesztett alulintegráltak.
} 


\section{RECENZIÓ}

ge kötés és kisebb kirekesztettségi érzet jár együtt. A nagyobb politikai aktivitás a normaszegés elutasítását is jelenti (kivéve a vállalkozók körében). A munkaerőpiaci hátrányokat (presztízs, jövedelem, munkakörülmények) akkumuláló foglalkozási kategóriák (munkanélküliek, betanított és segédmunkások) dezintegrációja és eltávolodása a társadalom többi csoportjától erőteljessé vált 2018-ra. Az eredmények kvintesszenciája, hogy a foglalkozási csoportok és a vizsgált integrációs mechanizmusok között értelmezhető összefüggés mutatható ki: az osztálymodell felső rétegei magasabb gyenge kötésszámról, alacsonyabb kirekesztettség-érzetröl és magasabb politikai részvételről számoltak be.

A következő fejezet a Struktúra és cselekvés. A politikai integráció mechanizmusai címet viseli (Gerő Márton és Szabó Andrea).

A politikai integráció mechanizmusai kapcsán a szerzők több elméleti modellt elemeznek és vetik össze azok állításait a témát vizsgáló empirikus kutatások eredményeivel. Ezeket a mechanizmusokat a habermasi keretben interpretálták, az empirikusan megfigyelhető mechanizmusokkal Charles Tilly állítását követve azt fogalmazzák meg, hogy a politikai szereplők a közpolitikai döntések esetén a társadalomszerkezet befolyásolására törekszenek. Ennek során stratégiai, kommunikációs és csoportkategóriákkal operálnak, a legitimációért folyó harc legfontosabb eszköze a csoportok közötti határok megváltoztatása (erősítése vagy gyengítése). E módosítások területeit a redisztribúciós politikák, a politikai kommunikáció és a bizalmi hálózatok jelentik.

Tanulmányuk további részében a habermasi modern tömegtársadalom elmélet két nagy szféráját elemzik, a közszférát (gazdaság és állam), és a magánszférát, az utóbbit körülvevő, átszövő informális kapcsolatrendszereket, a nyelvi és értékrendbeli szocializációs folyamatokon alapuló életvilágot. Az első szférát, a rendszer intézményeit a célracionalitás, míg az életvilágot a kommunikatív racionalitás szempontjai koordinálják (Habermas mellett részletesen elemzik Cohen és Arato [civil és politikai társadalom], Lipset és Rokkan [pártrendszerek és törésvonalak], valamint Tilly [a társadalomszerkezet és a politika jellemzői közötti kölcsönös függés, és a kategoriális egyenlőtlenségek befolyásolásán keresztül a hatalomszerzés feltételeinek a módosítása]) állításait. A politikai integráció rendszerszintű mechanizmusait a vonatkozó szakirodalom állításainak az elemzésével jellemzik, akárcsak az életvilág szintjét. Elemzik az életvilág szerkezetét, a politikai értékstruktúrát (melyet az amorális familizmus jellemez), a nyilvánosság szerkezetét és működését.

Összegző megállapításaikban megfogalmazzák, hogy a politikai szereplők következetesen és tudatosan a társadalomszerkezet befolyásolására törekszenek. A legitimációért folytatott küzdelemben a hatalom egyik legfontosabb eszköze a csoportok közötti határok megváltoztatása, gyengítése vagy élesebbé tétele. Minél zártabbak a társadalmi csoportok, minél nehezebb a társadalmi rétegek közötti kommuniká- 


\section{RECENZIÓ}

ció, annál könnyebb a hatalmi érdekek ellenállás nélküli átvitele. Ennek eredménye, hogy a Magyarországon kiépülő rendszer a társadalmi csoportok közötti kommunikációs folyamatokat akadályozza és a saját szempontjai szerint irányítja. A rendszer további sajátossága, hogy befolyásolási szándékaival szemben kevés az erőteljes ellenállás, úgy állítja elő a maga számára szükséges legitimációt, hogy irányítja a rendszer és életvilág közötti közvetítő folyamatokat.

A Redisztribúció és társadalmi integráció fejezetben az újraelosztásnak az integrációra gyakorolt hatását vizsgálják a szerzők (Balogh Karolina, Czibere Ibolya, Kovách Imre, Nemes-Zámbó Gabriella).

A jóléti redisztribúció mellett a projekt alapú, valamint a rekombináns redisztribúciót is elemzik a szerzők, részben korábbi tanulmányaikra támaszkodva és hivatkozva. A társadalmi jövedelmek kapcsán megfogalmazzák, hogy bár a szegénységben és a társadalmi kirekesztődés kockázatában élők aránya csökkent, de a legrosszabb helyzetűek tovább szegényedtek, ami a szociális transzferek korlátozott képességeit jelzi az újraelosztásban. A családtámogatásokban például a munkavállalási hangsúlyú támogatási rendszer azt eredményezte, hogy az eltérő társadalmi helyzetű családok közötti egyenlőtlenségek fokozódtak, a kedvezőbb helyzetű családok kiemelt szerepe erősödött. A munkanélküliség és a munkaerőpiac kezelésére (is) a „munkavállalást támogató" szemlélet és gyakorlat vált jellemzővé, átalakították a támogatási rendszert, a munkaerőpiaci intézményrendszert (azt a kormányhivatalok feladatává tették), és kiterjesztették a közfoglalkoztatást (a közmunka formájában).

A szerzők a redisztribúciónak az egyenlőtlenségeket a társadalmi transzfereken keresztül befolyásoló szerepét négy fő ellátási típus esetében vizsgálták (nyugdíjak, munkanélküli ellátások, családtámogatás, szociális ellátások). Azt állítják, hogy az alacsony összegű, rászorultsági elvű ellátások az iskolai végzettségek szerint lefelé szórnak, míg a munkaerőpiaci részvételhez (is) kötött családtámogatások inkább a középrétegekhez tartozók felé, amely a szegénypolitika túlsúlyát bizonyítja a szociálpolitikai elvek érvényesítése helyett. Ellentmondásos módon a szegénypolitikai túlsúly ellenére a rászorultsági juttatásokat kapó háztartásokban az ellátások ellenére is magas a deprivációban élők aránya, azaz a támogatások sem a szegénységet, sem a fogyasztási szegénységet (deprivációt) nem képesek enyhíteni. A szerzők véleménye az, hogy a jelenlegi pénzbeli transzferek elsősorban az egyenlőtlenségek fenntartására és növelésére alkalmasak, annak csökkentésére nem (az iskolai végzettség, a háztartásszerkezet és az integrációs csoportok jellemzői alapján). Ehhez járulnak még a projektalapú redisztribúció ellentmondásai, így a projektösszegekhez történő hozzáférés különbségei új társadalmi egyenlőtlenségek forrásaivá váltak.

Igen sommás a szerzők véleménye a kormányzat elosztási politikájáról, mely szerintük maga is növeli a társadalmi egyenlőtlenségeket: „a kormányzati redisztribúció vizsgált formái elsősorban a jobb helyzetű, a társadalom felső deciliseihez 


\section{RECENZIÓ}

tartozókat támogatják. A legrosszabb helyzetúek tudatos kiszorítása a redisztribúcióból példa nélküli a rendszerváltást követő magyar szociálpolitikai és társadalompolitikai rendszerek történetében" (141. o.).

Pálné Kovács Ilona A kormányzás területi (közép) integrációs szerepét járja körül tanulmányában.

Azt vizsgálja, milyen szerepet tölt be a középszintű kormányzás a társadalmi integrációban, a helyi önkormányzatok tevékenységének térségi összehangolásában. A „középszintű kormányzatok” számos nehézséggel küzdenek, helyzetük jellemzően ellentmondásos, feladat- és funkciórendszerük is nehezen megfogható, gyakran „kiüresedik”. A helyi, települési önkormányzatok legitimációja erős, közel vannak az emberekhez, velük szemben a területi kormányzatok „kényelmes” távolságban az emberektől, de „kényelmetlenül” közel vannak a kormányzás központi szintjéhez.

A szerző részletesen elemzi a területi kormányzás változásait az Európai Unióban és Magyarországon, utalva a különböző korszakok eltérő megközelítésmódjára és gyakorlatára, a centralizáció és a decentralizáció váltakozó hullámaira.

A középszint tipikus funkciója a koordináció, aminek a tartalma attól is függ, hogy az önkormányzatok milyen helyet birtokolnak a politikai-hatalmi szerkezetben. A középszintű területi önkormányzatok tipikus koordinációs feladatköre (lenne) a fejlesztéspolitika, és a térség településeinek, önkormányzatainak az öszszefogása. A szerző mélyrehatóan elemzi a hazai önkormányzati rendszer, benne a megyék és a megyei önkormányzatok helyzetének változásait a rendszerváltás óta. A legújabb változások eredménye, hogy a helyi önkormányzatok fontos helyi közügyek (oktatás, kórházak, egészségügy, szociális gondoskodás) felett vesztették el a rendelkezési jogukat, ezzel a helyi társadalom beleszólási lehetőségét. Végbement a megyei önkormányzatok által ellátott közszolgáltatási intézményrendszer államosítása is, ami a területi léptékü önkormányzati integrációs szerepkört kérdőjelezi meg, kialakult a centralizált (dekoncentrált) „helyi állam” modellje, az önkormányzatok helyére állami hivatalok léptek, korlátozott helyi kapcsolatrendszerrel. A kormányhivatalok alkotmányos jogállású, az önkormányzatoknál sokkal nagyobb hatalmat birtokló szervezetekké váltak, hatásuk a megyék társadalmi, gazdasági helyzetére lényegesen nagyobb lett a megyei önkormányzatokéhoz képest (172. o.).

A kötet ötödik fejezete Az önkormányzatok és a helyi társadalom integrációja címet viseli (Tamás Veronika).

A tanulmány a helyi társadalmi integrációval foglalkozik, azt mutatja be, hogyan történik néhány társadalmi csoport bevonása a helyi döntéshozatalba. A résztvevői kör kiszélesítésére irányuló törekvések az önkormányzatok és önkormányzati rendszerek több múködési módját alakították ki, bár az önkormányzati modellek vál- 


\section{RECENZIÓ}

tozásaira más tényezők is hatottak. Így a közelmúltban beszéltek a governance paradigmáról, az új lokalizmusról. A helyi szintú integráció három területen valósult meg, az állampolgárok és a civil szervezetek bevonásában, illetve a partnerségben a helyi gazdaság képviselőivel, a vállalkozókkal. A kétezres évek kutatásai szerint az együttműködések hálózatokon keresztül valósulnak meg - ennek az irányzatnak a bírálói szerint azonban a társadalmi rendet a korlátozó állam, a hálózatokat pedig a társadalmi elit tartja fenn. Ettől függetlenül fontos hangsúlyozni, hogy a társadalmi integrációt segítő mechanizmusok helyben közvetlenebbül fejtik ki hatásukat, a bevonódás és az érintettség miatt. Ugyanakkor a helyi szintű integrációt több dolog is hátráltatja, így az önkormányzati kompetenciák és hatáskörök, valamint a rendelkezésre álló források csökkenése, továbbá a helyi vezetés és a helyi elit kontraszelekciója.

Hasonlóan fontos a helyi integráció szempontjából (is) az állampolgári részvétel: a hagyományos politikai részvétel (tagság pártban és szervezetben, választási részvétel), a direkt demokratikus (tiltakozás, petíció) és az új típusú, online aktivitások. A szerző ezek kapcsán tipikus különbségeket feltételezett a különböző társadalmi csoportok között, a társadalmilag integrált csoportok magasabb részvételét és aktivitását, és magasabb szubjektív kompetenciát várt - ezek igazolódtak is, így például az erősebben integrálódott csoportok esetében aktív befolyásoló tevékenység figyelhető meg.

A civil szervezetek részvételére a helyi döntésekben többféle modellt találunk a szakirodalomban, melyek a bevonódás, bevonás módjára és a civil szervezeteknek az önkormányzatokkal kialakult kapcsolatára vonatkoznak (periférikus, participatív, patrónus és partneri). A kapcsolat nagyon sokszínű, ami abból is fakad, hogy a helyi politika kisebb léptékű. A vállalkozói csoportokkal való együttmúködés is igen változatos, a fejlesztési források közös megszerzésétől a településfejlesztésen át a vállalkozók támogatásának nagyon sokféle módjáig (kedvezmények, támogatások, a lobbi tevékenység elfogadásáig és politikai pozíciók biztosításáig) terjed.

Gerő Márton és Kerényi Szabina a civil társadalom változó szerepeit vizsgálja írásában (A civil társadalom változó szerepei és a társadalmi integráció).

Arra tesznek kísérletet, hogy a civil társadalom integrációs szerepére gyakorolt hatását vizsgálják (a civil szervezetek szűkülő lehetőségeinek a körülményei között) az adott politikai kontextus keretei között. Hangsúlyozzák, hogy a civil társadalom a közéleti és az akadémiai diskurzusokban mint a társadalmi egyenlőtlenségek és a demokratikus intézmények felszámolása elleni harc „védőbástyája” jelenik meg. E túlzó elvárásokat magyarázatához figyelembe kell venni a fogalom újjászületésének sajátos történelmi helyzetét. Ez a rendszerváltás idejének várakozásait foglalja magába, melyek a demokratikus intézmények megerősítésére és a társadalmi integrációra vonatkoztak. 


\section{RECENZIÓ}

A szerzők a civil társadalom fogalma alatt az állam és a gazdaság rendszerszerű intézményei és a társadalom informális hálózatai közötti nyilvános, önkéntes társuláson alapuló formális és informális szerveződéseket és ezek hálózatát értik. Elemzik a civil társadalomra vonatkozó főbb elméleteket, és vázolják a civil szervezetek és a társadalmi mozgalmak kapcsolatának a változásait. Bemutatják a civil társadalom és szervezeteik funkcióit is, melyek a következők: a deliberatív eljárások alkalmazásának a kikényszerítése, a demokratikus értékrend társadalmi beágyazása, és a különböző társadalmi csoportok közötti kapcsolatok biztosítása. A társadalmi mozgalmak kétféle integrációs mechanizmust jelenthetnek: a mozgósításon keresztül összehangolják az állampolgárok probléma- és célmeghatározásait (keretezés, framing), továbbá az önkéntes munkákra való mozgósítással hozzájárulnak a közjavak előállításához is.

A tanulmányban nemcsak az elméleti modellekről olvashatunk, a szerzők a civil társadalom és szervezetek helyzetének változását is elemzik. Ennek kapcsán megfogalmazzák, hogy 2010 után alapjaiban változott meg az állam és a civil társadalom viszonya. „Ez a változás lényegében három tényezőben mutatkozik meg: a jogszabályi változásokban, az állam és állampolgár közötti kommunikációs metódusokban és a civil társadalom szervezeteinek állami szervezetek által való zaklatásában" (220. o.). A civil szervezetek stigmatizálása mellett számos GONGO-t hoztak létre, melyek függetlennek és civilnek tartják magukat. A közelmúlt folyamatai alapján a szerzők véleménye az, hogy a civil társadalom átalakulása következik be politikai és kulturális értelemben, ami jogszabályi, támogatási és diszkurzív szinten is jelentkezik. A civil részvétel is egyre inkább pártossá, pártpolitikai aspektusból polarizáltabbá válik.

A kötet hetedik tanulmánya a munkaerőpiaci integrációs mechanizmusokat vizsgálja (Illéssy Miklós, Huszár Ákos, Csizmadia Péter: Rugalmasság biztonság nélkül: munkaerôpiaci integrációs mechanizmusok Magyarországon a 2010-es években).

A szerzők abból indulnak ki, hogy a társadalom tagjainak a munkavégzés nemcsak jövedelemforrás, hanem a társadalmi integráció eszköze is. Kitérnek a jóléti állam és a munkaerőpiac elemzésére, a foglalkoztatási gyakorlat „rugalmasabbá” tételére (gyors létszámváltoztatások, munkaerő-kölcsönzés, határozott idejű szerződés). Ezek mellett a folyamatok mellett utalnak az európai szociális modell többé-kevésbé érvényesülő elemeire: a munkavállalói jogokra, az univerzális és fenntartható szociális védelemre, az inkluzív munkaerőpiacra, a működő társadalmi párbeszédre, a magas szintű közszolgáltatásokra, és a szolidaritásra (mint társadalmi inklúzióra és kohézióra).

A foglalkoztatási és munkaerőpiaci folyamatokat elemző tanulmány a hazai viszonyok felvázolásakor megállapítja, hogy 2010 után a hazai munkaerőpiac alapvetően átalakult. A kormányzat („új rezsim”) önértelmezésében a jóléti állam he- 


\section{RECENZIÓ}

lyett a „munkatársadalom” kiépítésén dolgozik, a „segély helyett munkát” elv alapján csökkentette a szociális alapon folyósított transzferjövedelmek szintjét és csökkentette azok jogosultsági idejét. Emellett felfuttatta a kötelező közmunka rendszerét, és számos egyéb változtatást is eszközölt (adózás, tanköteles kor leszállítása, korai nyugdíjazás szigorítása, rokkantnyugdíjas státusz megszüntetése, nyugdíjkorhatár emelése).

A tanulmány a továbbiakban a foglalkoztatási szerkezet változásait, majd a szegénység és a jövedelmi egyenlőtlenség jelenségeit elemzi. Megállapítják, hogy a jövedelmi szegénység leginkább a munkanélkülieket sújtja, a nyugdíjasok helyzete pedig ellentmondásosan alakult, hisz hosszabb időszakon keresztül a nyugdíjasok helyzete más csoportokhoz képest kedvezően alakult, ám az utóbbi években egyre magasabb szegénységi ráta jellemzi őket. Egyúttal - a magasabb foglalkoztatás ellenére megnőtt azoknak az aránya, akik ugyan dolgoznak, munkával jutnak jövedelemhez, a keresetük azonban nem elég arra, hogy elérjék a szegénységi küszöböt.

A szerzők következtetése (a szakirodalom és kutatásaik alapján) az, hogy a mai magyar kormány a munkaerőpiacon kívánja integrálni a társadalmat, és gyengébb védelmet nyújt azoknak, akik öregségük, betegségük, vagy munkanélküliségük miatt kiesnek a munkaerőpiacról. A „visszatérőkre” gyakran a végzettségüknek nem megfelelő munka vár, ez a kényszer pedig leginkább azokat érinti, akik a legkisebb erőforrásokkal rendelkeznek, és a legkevésbé konfliktusképesek, a legkevesebb időt és erőforrást tudják rászánni az álláskeresésre: a nőket, a fiatalokat és az idősebbeket. Az egyenlőtlenséget növelő politika és szisztéma két dolog miatt nem vezetett nyílt társadalmi konfliktushoz: a külföldi munkavállalás lehetősége, illetve a 2013 utáni gazdasági növekedés miatt, ami nagyszámú munkaerő felvételét tette lehetővé.

A nyolcadik fejezet címe: Társadalmi integráció, egészség, egészségügy (Kollányi Zsófia).

A szerző az általános egészségi állapot kapcsán megfigyelhető, erős összefüggésekre alapozza tanulmányát: az egészségi állapot alacsony szintje vagy egyenlőtlen eloszlása a társadalmi csoportok között arra utal, hogy valami nincs rendben az adott társadalomban - miközben az egészségi állapot konzerválja is az egyenlőtlenségeket. A tanulmány erre az oda-vissza hatásra, és ennek a magyarázatára fókuszál. Ebben az értelemben az egészségi állapot az integráció feltétele és következménye is. Így például egy társadalom integrációs mechanizmusainak a múködésétől is függ az alacsonyan képzettek és a valamilyen egészségkárosodással élők munkaerőpiaci esélyei. Az egészségi állapot ugyanakkor az integráció következménye és mutatója is, hisz az egészségi állapotot alakító faktorok között (biológiai, környezeti, társadalmi faktorok, az egyén életmódja) a társadalmi integráció, a társadalom integráltsága is jelen van. Az egészségi állapotot az erőforrásokhoz (tudás, pénz, hatalom, presztízs, társadalmi kapcsolatok) való hozzáférés is alakítja, melyekre ugyancsak 


\section{RECENZIÓ}

hat az integráció. Az „alapvető okok” elmélete alapján a társadalmi struktúra jellege, az abban betöltött hely, és a társadalmi integráció mechanizmusainak a milyensége együttesen határozzák meg a négyféle (említett) kulcserőforráshoz való hozzájutást.

A továbbiakban a tanulmány néhány empirikus megállapítására utalok (a szerző szakirodalom-elemzése és saját kutatásai alapján). Az egyik ismert összefüggés az egészségi állapot és a GDP egy főre eső mutatója, a jövedelem, a közszolgáltatások, a közfinanszírozott oktatás és egészségügy, a köz- és a jogbiztonság között figyelhető meg. Az egészségi állapot szoros kapcsolatban áll a társadalmi státusszal, az iskolázottsággal, akárcsak a társas kapcsolatok, a társadalmi tőke és a társadalmi kohézió.

A téma szempontjából talán legfontosabb empirikus eredmény, hogy a hét integrációs csoport két részre bomlik az egészségi állapot szempontjából. A rossz (az átlagnál rosszabb) egészségi állapot a normakövető dezintegráltak és a kirekesztett alulintegráltak csoportjában detektálható. Fontos, hogy a kirekesztettség szubjektív érzete összefüggésben áll a strukturális körülményekkel. Ez alapján állítja azt a szerző, hogy a magyar társadalmat mély szakadékok szabdalják szét az egészségi állapot szempontjából, és ezek a szakadékok, úgy tűnik, jobbára egybeesnek a jellemzően strukturális egyenlőtlenségek törésvonalaival (316. o.).

Bárdi Nándor Magyarország és a határon túli magyarok viszonyáról ír a kötet kilencedik fejezetében.

A szerző a magyar államnak a határon túli magyarokkal kapcsolatos, az elmúlt három évtizedbeli politikáját tekinti át. Ennek az integrációs kérdésnek az az alapja, hogy a magyar etnokulturális közösség és Magyarország határai nem esnek egybe, a határon túli magyarok pedig a történetileg szétszakított közösségben egyenrangúként kívánnak jelen lenni.

A többi tanulmány esetében „az értő bemutatásra” törekedve elsősorban a tanulmányok ismertetésére, a főbb eredmények kiemelésére törekedtem. Bárdi Nándor tanulmánya, annak a témája nagyon értéktelített, alkalmas lehet a normatív megközelítésmód alkalmazására, és az értékelköteleződésre a szerző oldaláról, ám tegyük hozzá, erre nem kerül sor. A szerző elkerülte a téma buktatóit és csapdáit, magas színvonalú szakmai tudományos elemzését adta a vizsgált kérdésnek - ezt fontosnak tartottam előrebocsátani a tanulmány főbb eredményeinek az ismertetése előtt. Maga a tanulmány történeti, szociológiai és politológiai aspektusokból közelít a témához.

Elsőként a kormányzati stratégiákat tekinti át, 1920 és 2020 között. E stratégiákra az egyes korszakok hazai és nemzetközi folyamatai nagy hatást gyakoroltak, a stratégiák között nagyon lényeges különbségek ragadhatók meg a revízió gondolatától a téma elhallgatásán át könnyített honosításig és a határon túli magyarok intézményépítő és gazdaságfejlesztő támogatásáig. 


\section{RECENZIÓ}

A tanulmány szerint fontos kérdés, hogy miről és hogyan beszélünk. Ide tartozik az érintettek megnevezése (pl. a „külhoni magyar” a „Kárpát-haza”, vagy a diaszpóra kérdése). A földrajzi jelentéstartalom a Felvidék, Délvidék megnevezések használatára utal, ami azonban magyarországi szempontokat sugall, akárcsak az „anyaország” és az „anyanemzet” terminusok. A szerző áttekinti a magyar-magyar viszony kölcsönös alakulását is, a témára vonatkozó empirikus kutatások eredményei tükrében. A hetvenes-nyolcvanas években a hazai közvélemény a magyarsághoz tartozás meghatározó kritériumának az állampolgárságot, az országhoz kötődést tekintette, kevésbé a (határon túli magyarok) nyelvtudását, vagy a magyar kultúrához való kötődését. A nyolcvanas évek végére a határon túliak elfogadása érzelmi kérdés volt, ebben szerepet játszott például a romániai viszonyok tematizálása a magyarországi médiában, az ott élő magyarok helyzetének a bemutatásával. Ez is szerepet játszott abban, hogy a kilencvenes évek elejére a magyarországi közvélemény már nem tekintette a másik ország belügyének az ott élő magyarok helyzetét.

A kétezres évek empirikus szociológiai kutatásai azt jelezték, hogy a határon túli magyarok magyarországi megítélésében a székelyek és az erdélyi magyarok a legrokonszenvesebbek. A több országban folytatott kutatások eredményei alapján az látható, hogy a magyarországi magyarok a kompetenciák terén felülértékelik magukat a más országokban élő magyarokhoz képest, miközben morálisan pozitívabban értékelik őket. A határon túli magyarok magyarországiakról kialakult képe több közös vonást, de több eltérést is mutat. A Balázs Ferenc Intézet kutatása alapján a magyarországiakról kialakult képben egyszerre van jelen a beképzelt és lekezelő magatartás a határon túliakkal szemben, miközben modellértékűnek tekintik a magyarországi magyarok kulturális kompetenciáit. A szlovákiai magyarok megítélése egyértelműbben pozitívabb a magyarországiakról, az erdélyiek és a vajdaságiak azonban a nemzeti identitáshoz való gyengébb ragaszkodás és az elidegenedett emberi viszonyok miatt azok kritikája jelenik meg az anyaországi magyarokról, a kárpátaljaiak a nemzeti kötődést kevésbé hiányolták, az értékrendbeli másságot látták jelentősebbnek.

A magyarországi közvélemény megosztottá vált a határon túli magyarok támogatása ügyében, erre a pártok által képviselt vélemények is jelentős hatást gyakoroltak. A többség egyetért a határon túli magyarok állami támogatásával, különösen, ha az kulturális segítségnyújtás, és az az anyaföldön való boldogulás támogatása. Kevésbé elfogadott, és ezekben a kérdésekben erősen hat a pártszimpátia, az állampolgárság megadása, az ezzel együttjáró szavazati jog, a (magyarországi) egészségügyi ellátás igéybevétele és a kisebbségi politikai kapcsolatépítés.

Az 1990 utáni kormányzati magyarságpolitikáknak csak a fóbb elveire utalok, az egyes kormányzatok politikáját, annak eszközrendszerét, a támogatások területeit nem mutatom be - fontos megjegyezni, hogy ezeket a kérdéseket a szerző alaposan és objektíven elemzi.

A kormányzati magyarságpolitikák elveit a következőkben nevezi meg a szerző: a történelmi felelősség elve, a szolidaritás elve, a családi, rokoni, baráti viszonyok, és a 


\section{RECENZIÓ}

térség stabilizálása. A politikai elképzeléseket öt lehetséges csoportba lehet sorolni, melyek: a Tündérkert-vízió, az egységes nemzet koncepciója, az államközi, külpolitikai kezelési mód, a regionalista elképzelés és a migrációs, demográfiai elképzelés (ez utóbbit a politikai szereplők nyilvánosan nem vállalják).

Szót kell még ejteni a magyarságpolitika konszenzusának elveiről, melyet a hazai politikai szereplők elfogadnak: nem a határok helyét, hanem azok minőségét kell megváltoztatni, a szomszédos országokban élő magyarság önálló kulturális intézményrendszerre jogosult, a határon túli magyar politikai élet szereplőit egyenrangú partnerként kell elfogadni, képviseletük a nemzetközi fórumokon a magyar kormányzatok feladata, a magyarországi költségvetésnek része a határon túli magyarság támogatása.

A szerző a következő gondolattal zárja tanulmányát: „A magyar politikai elit megosztott a határon túli magyarok integrációja ügyében. Míg a magyar baloldal a kisebbségi magyar politika és a szomszédországi politikai elitek megegyezését szorgalmazza, hosszú távon bízva a kisebbségi autonómiák létrejövetelében, addig a jobboldal a kisebbségi magyar közösségeket a magyar politikai közösség természetes részének tekinti (saját közösségéhez számítva őket), amely az újraszerveződő - egyszerre transznacionális és öntudatos nemzetállami - Közép-Európában az „anya”-ország segítségével építheti ki pozícióit szülőföldjén.” (377-378.o)

A kötet zárófejezete a Kontextus vagy kontaktus? Elöitélet-rendszerek és migrációs tapasztalatok címet viseli (Papp Z. Attila, Zsigmond Csilla).

A szerzők a migrációs tapasztalat és a migrációs érintettség, illetve a társadalmi integráció előítéletekre gyakorolt hatását vizsgálják. Kiemelik, hogy a nemzetközi összehasonlító vizsgálatok alapján Magyarországon nagymértékű az idegenellenesség, amely egy általánosabb (európai) kelet-nyugat kognitív lejtőn is értelmezhető. Ezen túlmenően a nemzetközi és a hazai szakirodalom is hangsúlyozza, hogy a férfiak és az idősebbek elutasítóak, a magasabb iskolai végzettségúek pedig toleránsabbak a különböző etnikai és társadalmi csoportokkal szemben. A társadalom vesztes csoportjai körében is magasabb az idegenellenesség, akárcsak a politikailag kevésbé aktívak, és a nagyvárosiak körében (ami a nagyvárosiak iskolázottságát, foglalkoztatási mutatóit tekintve akár meglepő is lehet).

A szerzők Allport kontaktus-hipotéziséhez kötik elemzésüket, mely abból indul ki, hogy az előítéletesség leginkább a különböző társadalmi csoportok közötti gyakori és rendszeres kapcsolatokkal csökkenthető, míg más kutatók szerint a kapcsolatok sűrűsége nem minden esetben csökkentette az előítéletességet és a sztereotípiákat. Ez alapján fogalmazódik meg a tanulmányban, hogy a migrációs tapasztalat a kontextus és a kontaktushatás révén befolyásolhatja az elóítéletességet, és a külföldi idegenségtapasztalat is hatással lehet az idegenellenességre. 


\section{RECENZIÓ}

A tanulmányban ismertetett empirikus kutatási eredmények több területen, így az iskolai végzettség és a lakóhely esetében igazolták a várakozásokat. A migrációs tapasztalatnak (külföldi munkavállalás) is jelentős hatása van, a külföldi munkatapasztalattal rendelkezők kritikusabbak saját honfitársaikat illetően, de elfogadóbbak a menekültekkel és más kisebbségi csoportokkal szemben. A társadalmi integráció és az előítéletek kapcsán elemzett erős és gyenge kötések hatása sajátos mintázatot mutat. Az erős kötésekkel rendelkezők pozitívan viszonyulnak a saját csoporthoz és a többi „nemzeti” csoporthoz, de elutasítóak több, kisebbségi társadalmi csoporttal szemben (kábítószeresek, migránsok, arabok, románok). A gazdag kapcsolatháló, a sok gyenge kötés viszont elfogadóvá tesz az összes (vizsgált) társadalmi csoportokkal szemben, ami azt jelenti, hogy az integráltság (sok gyenge kötés) csökkentheti a más csoportokkal szembeni előítéletet. A szerzők három toleránselfogadó vélemény együttest azonosítottak, melyek mindegyike valamilyen csoportok elfogadását jelenti. A „távoli” idegen csoportok (pl. migránsok, menekültek, muszlimok) elfogadását, a „közép-kelet-európaiságot” elfogadókat (szerbek, ukránok, románok pozitív megítélése alapján), és egy explicit-etnocentrikus beállítódást, mely a bárhol élő magyarok elfogadását jelenti. 